Review

\title{
The Relationship between Follicle-stimulating Hormone and Bone Health: Alternative Explanation for Bone Loss beyond Oestrogen?
}

\author{
Kok-Yong Chin ${ }^{凶}$ \\ Department of Pharmacology, Faculty of Medicine, Universiti Kebangsaan Malaysia Medical Centre, Malaysia. \\ $\triangle$ Corresponding author: Department of Pharmacology, Level 17, Preclinical Building, Universiti Kebangsaan Malaysia Medical Centre, Jalan Yaacob Latif, \\ Bandar Tun Razak, 56000 Cheras, Kuala Lumpur, Malaysia. Tel: +603 9145 9573; Fax: +603 9145 9547; Email: chinkokyong@ppukm.ukm.edu.my \\ (C) Ivyspring International Publisher. This is an open access article distributed under the terms of the Creative Commons Attribution (CC BY-NC) license \\ (https://creativecommons.org/licenses/by-nc/4.0/). See http://ivyspring.com/terms for full terms and conditions.
}

Received: 2018.04.08; Accepted: 2018.08.27; Published: 2018.09.07

\begin{abstract}
Bone loss in women commences before the onset of menopause and oestrogen deficiency. The increase of follicle-stimulating hormone (FSH) precedes oestrogen decline and may be a cause for bone loss before menopause. This review summarizes the current evidence on the relationship between FSH and bone derived from cellular, animal and human studies. Cellular studies found that FSH receptor (FSHR) was present on osteoclasts, osteoclast precursors and mesenchymal stem cells but not osteoblasts. FSH promoted osteoclast differentiation, activity and survival but exerted negligible effects on osteoblasts. Transgenic FSHR or FSH knockout rodents showed heterogenous skeletal phenotypes. Supplementation of FSH enhanced bone deterioration and blocking of FSH action protected bone of rodents. Human epidemiological studies revealed a negative relationship between FSH and bone health in perimenopausal women and elderly men but the association was attenuated in postmenopausal women. In conclusion, FSH may have a direct action on bone health independent of oestrogen by enhancing bone resorption. Its effects may be attenuated in the presence of overt sex hormone deficiency. More longitudinal studies pertaining to the effects of FSH on bone health, especially on fracture risk, should be conducted to validate this speculation.
\end{abstract}

Key words: follicotropin; gonadotropins; menopause; osteopenia; osteoporosis; skeleton.

\section{Introduction}

Accelerated bone loss in women during menopausal transition is often attributed to oestrogen deficiency. However, the Study of Women's Health Across the Nation (SWAN) involving women from various ethnic groups showed negligible changes in the bone mineral density (BMD) in pre- and early perimenopausal women. Significant bone loss was observed in late perimenopausal women $(0.018$ and $0.010 \mathrm{~g} / \mathrm{cm}^{2}$ yearly at the spine and hip) and the rate increased in postmenopausal women $(0.022$ and 0.013 $\mathrm{g} / \mathrm{cm}^{2}$ yearly at the spine and hip) [1]. On the other hand, the decline of oestrogen level transpires very late during perimenopause but the gonadotropin levels, especially follicle-stimulating hormone (FSH), gradually increase 5-6 years before menopause $[2,3]$.
Thus, oestrogen deficiency alone may not explain the accelerated bone loss during this period.

Although ovariectomy in female rodents invariably causes a reduction in bone mass, studies that inhibit the function or knockout the oestrogen receptors (ERs) in rodents showed contradictory results. Ogawa et al. (2000) generated a rat model with a dominant negative ERa which inhibited both ERa and ER $\beta$. The transgenic rats showed similar BMD with the wildtypes. After ovariectomy, the transgenic rats also showed a similar degree of bone loss compared with the wildtype, and the condition could not be reversed with oestrogen replacement [4]. In another study, ER $\beta$ knockout female mice showed increased bone mineral content at the cortical bone 
compared to the wildtype at 11 weeks old, as well as increased trabecular BMD and bone volume at 1 year old. The ER $\beta$ knockout male mice showed similar skeletal phenotypes as the wildtype $[5,6]$. The importance of oestrogen in maintaining bone health was further complicated by the fact that hypophysectomy inhibited high bone turnover induced by ovariectomy in rats [7]. Subsequently, Sun et al. (2006) observed that FSH receptor (FSHR) knockout mice maintained their bone health despite being hypogonadal [8]. Despite receiving criticisms on the model used, their research raised the question whether FSH plays a more vital role in regulating bone loss among women during menopause transition period.

The controversy on the role of FSH on bone metabolism remains to-date. The studies aforementioned hint a negative impact of high FSH on bone health. However, sex hormone deprivation therapy using gonadotropin agonists for the treatment of prostate cancer has been shown to induce bone loss in animals and humans [9-11]. Most importantly, oestrogen-centric therapies, such as hormone replacement therapy and selective oestrogen receptor modulator, have been successful in treating postmenopausal osteoporosis and preventing fractures [12-14]. Considering the complexity of this issue, this review aims to summarize the current evidence on the skeletal effects of FSH from cellular, animal and human studies. This issue is relevant because it can potentially shift the paradigm of an oestrogen-centric explanation for bone loss during menopause transition period. It may also offer a new avenue for the treatment of postmenopausal bone loss.

\section{Mechanism of FSH action on bone cells}

Protein and mRNA expression of FSHR have been detected in human monocytic cells (sharing the same lineage with osteoclast), osteoclasts and mesenchymal stem cells at a concentration lower than in ovarian samples $[8,15]$. However, they were absent in human osteoblasts [15]. The FSHR expressed in these cells belonged to the type-2 FSHR isoform and the expression level was not influenced by sex hormones [15]. The blocking of FSHR with mono- or polyclonal antibodies abolished the formation of osteoclast-like cells from bone marrow macrophages from mice [16]. Similarly, the promoting effects of FSH on osteoclast formation was impaired in bone marrow macrophages from FSHR knockout mice [16]. These studies showed that FSHR is essential for the action of FSH in promoting osteoclast formation.

Sun et al. (2006) showed that FSH increased osteoclast differentiation in human peripheral blood macrophages, mouse bone marrow culture and RAW cells but did not influence the proliferation of osteoclast precursors directly [8]. On the other hand, FSH induced the production of tumour necrosis alpha (TNFa) in monocytes and bone marrow macrophages from mice $[15,17]$, which in turn promoted the proliferation of osteoclast precursor cells as illustrated in cellular and in silico studies [17]. Several pathways related to osteoclast formation in monocytes were activated by $\mathrm{FSH}$, including osteoclast differentiation (toll-like receptor and interleukin-1 receptorassociated kinases), cell adhesion, survival (anti-apoptotic TNFs/nuclear factor-kB/B-cell lymphoma 2 (BCL-2)) and cytoskeletal remodelling [15]. FSH promoted the formation of tartrate-resistant acid phosphatase (TRAP) positive cells (osteoclast-like cells) from various types of macrophages (RAW 264.7 cells, RAW c3 cells, bone marrow macrophages from mouse) through FSHR [18]. This process was mediated by the ability of FSH to activate pathways essential to osteoclastogenesis, such as phosphorylation of protein kinase B (Akt) and extracellular-signal-regulated kinase (Erk), and nuclear translation of c-fos [18]. FSH also increased the formation of resorption pits and action ring of osteoclast-like cells, as well as promoted their survival [18]. This corroborated with the findings of Robinson et al. (2010) [15]. In short, FSH increases the proliferation of osteoclast precursors indirectly through inflammatory cytokines, as well as their differentiation into mature osteoclasts through direct interaction with the signalling pathways involved. Furthermore, it also promotes the bone resorption activity of osteoclasts.

Apart from $\mathrm{TNFa}$, osteoclast formation also requires the interaction between receptor activator of nuclear factor $\mathrm{k}-\mathrm{B}$ (RANK) on osteoclast surface and RANK ligand (RANKL) secreted by osteoblast. Cannon et al. (2011) showed that FSH at $50 \mathrm{mIU} / \mathrm{ml}$ (physiological FSH level in perimenopausal women) promoted the expression of RANK on human CD14+ monocytes [19]. However, at $100 \mathrm{mIU} / \mathrm{ml}$ (physiological FSH level in postmenopausal women), the effect of FSH was attenuated [19]. Similarly, Wang et al. (2015) found that with increasing concentration of FSH, the mRNA expression of RANK increased concurrently with other markers of osteoclast differentiation (TRAP, MMP-9 and cathepsin K) in RAW 264.7 cells [20]. Thus, FSH-induced osteoclastogenesis may be a result of increased RANKL-RANK interaction.

Conversely, negative results on the effects of FSH on osteoclast formation have also been reported. Ritter et al. (2008) showed that FSH did not affect the resorption pit area and formation of osteoclasts from 
human mononuclear cells and RAW cells [21]. However, at $3 \mu \mathrm{g} / \mathrm{ml}$, FSH decreased the formation of multinucleated TRAP-positive cells [21]. FSH also did not affect the gene expression of osteoclast markers, such as TRAP, calcitonin, MMP-9, aquaporin 9, $\mathrm{V}_{0}$ ATPase, TRAF6 and FSHR. The concentration difference could contribute to the discrepancy of this study with the previous ones [21].

Sun et al. (2006) showed that FSH did not influence the formation of mineralized nodules by colony forming units in mice bone marrow culture. It also did not affect the synthesis of RANKL [8]. This was not surprising since FSHR was absent in osteoblasts. Since mesenchymal stem cells displayed FSHR and the differentiation of osteoclasts required soluble factors from other cells, the indirect action of FSH in promoting osteoclastogenesis was tested. Sun et al. (2006) found that coculturing stromal cells, which was supposed to produce factors stimulating osteoclast formation, with $\mathrm{FSHR}^{-/}$macrophages in the addition of FSH did not stimulate osteoclastogenesis [8]. Considering all evidence above, the effects of FSH on osteoclast formation is direct, without the involvement of osteoblasts or stromal cells.

Despite the absence of FSHR and the lack of effects in osteoblasts, FSH could enhance the osteogenic potential of mouse embryonic fibroblasts, indicated by increased bone morphogenetic protein 9 (BMP-9) and alkaline phosphatase activity [22]. Combination of FSH and BMP-9 transfection increased the protein and mRNA expression of osteoblast markers (osteopontin and osteocalcin) and matrix mineralization in embryonic fibroblasts [22]. This was mediated by increased phosphorylation Smad1/5/8 and expression of transcription factors osterix and runt-related factor-2 essential in osteoblast formation [22]. When the transfected cells were injected into the flank of nude mice, they formed a bony mass [22]. Although being an innovative therapeutic approach, the use of genetically manipulated fibroblasts prevents the interpretation of FSH action on bone formation in normal physiology.

Therefore, the FSH seems to exert a direct effect on osteoclasts by promoting their formation, resorption activity and survival through FSHR. FSH enhances the osteogenic potential of pluripotent stem cells but its action on osteoblasts remains unclear due to the absence of FSHR in osteoblasts (Figure 1).

\section{Animal studies}

Sun et al. (2006) piloted the study on the skeletal effects of FSH using FSHR knockout (FSHR-/-) female mice [8]. These mice were hypogonadal but their bone

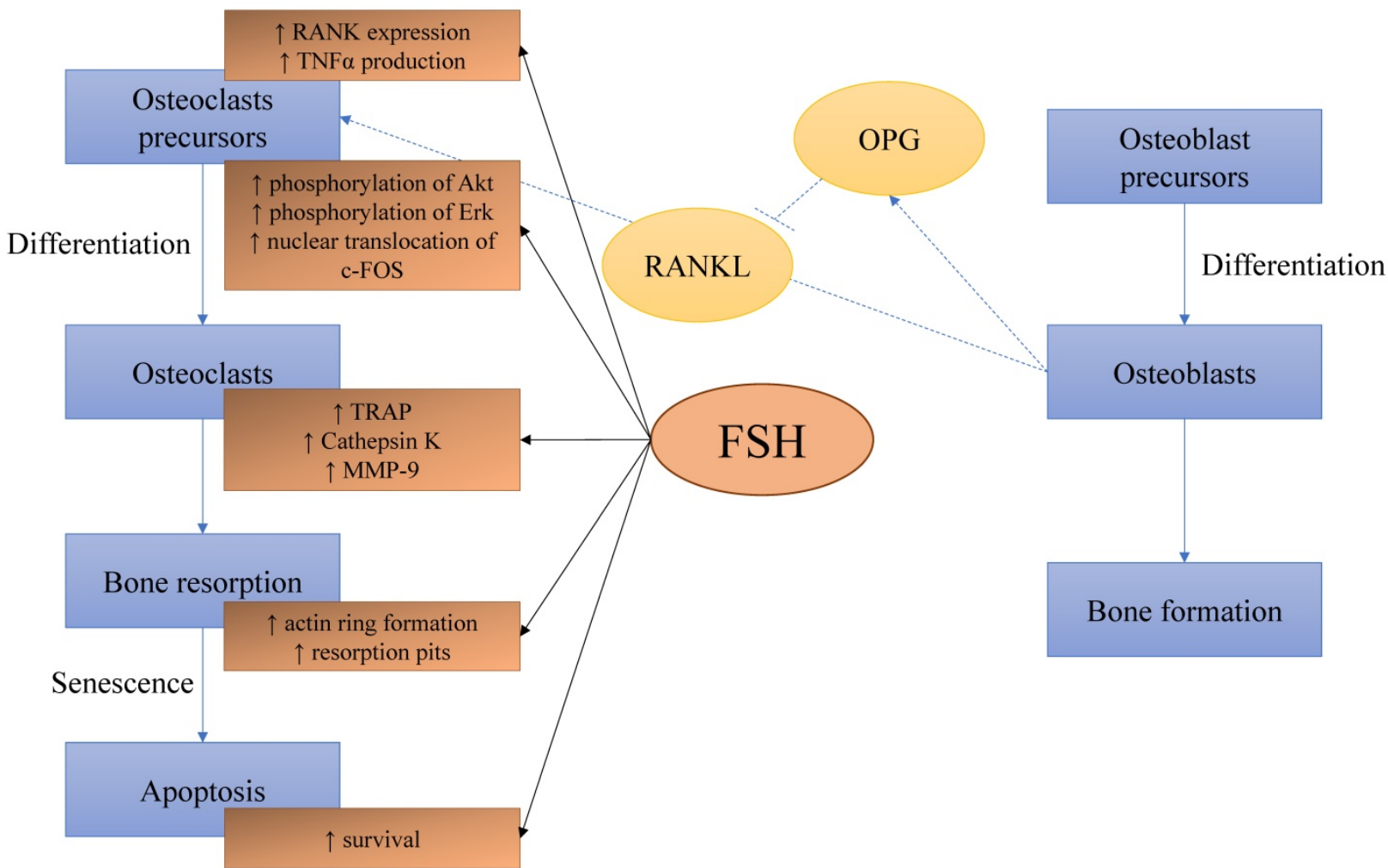

Figure 1. The direct effects of FSH on bone cells. FSH increases the expression of RANK and production of TNFa by osteoclast precursors. It also enhanced pathways leading to osteoclast differentiation. Formation of actin ring and resorption pits increase with FSH. It also prevents the apoptosis of osteoclasts. The effects of FSH on osteoblasts are not clear. Abbreviation: Akt=protein kinase B; c-FOS=Fos proto-oncogene; Erk=extracellular-signal-regulated kinase; FSH=follicle-stimulating hormone; MMP-9=matrix metallopeptidase 9; OPG=osteoprotegerin; RANK=receptor activator of nuclear kactor $\mathrm{K} B$; RANKL= RANK ligand 
status in terms of areal BMD, femoral trabecular microstructure and bone remodelling markers were similar with the wildtype mice [8]. This showed that eliminating the interaction between $\mathrm{FSH}$ and bone protected bone health in these hypogonadal mice. Culture of calvarial bone extracted from mice showed that FSH and RANKL enhanced formation of TRAP-positive surface in wildtype samples but not in FSHR ${ }^{-1}$ samples [8]. This observation was in accordance with the in vitro osteoclast generation assays using macrophages. FSH $\beta$ knockout mice (FSH $\beta^{-/-}$) shared similar skeletal features with FSHR-/mice. On the other hand, FSH $\beta$ haploinsufficient $\left(\mathrm{FSH} \beta^{+/-}\right)$female mice, which were eugonadal, had a higher femoral BMD but similar lumbar spine, femoral neck and tibial BMD compared with the wildtype and $\mathrm{FSH} \beta^{-/}$mice [8]. Femoral cortical thickness and trabecular structural indices were higher in the $\mathrm{FSH} \beta^{+/-}$mice compared to the wildtype [8]. This was expected since the presence of oestrogen and the attenuated FSH interaction provided protections to the bone of these mice. TRAP-labelled resorption surfaces and serum TRAP level were reduced in the $\mathrm{FSH} \beta^{+/-}$mice but mineralising surface and mineral apposition rate were similar in both the $\mathrm{FSH} \beta^{+/-}$mice and the wildtype mice [8]. mRNA expression of TRAP, cathepsin $\mathrm{K}$ and RANK were reduced in the bone marrow of $\mathrm{FSH} \beta^{+/-}$mice compared to wildtype [8]. This reflects a reduced osteoclast differentiation in the bone of these mice. This study received criticism for overlooking the fact that $\mathrm{FSHR}^{-}$- female mice had very high testosterone level, which could be accountable for the observed bone-sparing phenomenon [23]. The increased testosterone level was due to the double negative feedback actions, whereby the pituitary synthesised higher LH level in the absence of FSH, which in turn increased the production of testosterone by theca cells in the ovaries. As a result, raised testosterone level and uterine degeneration had been observed in FSHR $\%$ mice [23-25]. Hence, the use of transgenic animals cannot fully resolve the skeletal action of FSH due to changes in the hormonal milieu.

By contrast, Gao et al. (2007) showed that FSHR $\%$ mice demonstrated lower femoral and lumbar spine BMD values starting from month three of age compared to wildtype [26]. The trabecular bone volume, osteoblast number, bone formation rate and mineral apposition rate were also lower in these mice compared to the wildtype [26]. Concurrently, osteoclast number, RANKL/OPG number were significantly higher in $\mathrm{FSHR} /$ - mice compared to the wildtype [26]. The cause of these degenerative bone changes was oestrogen deficiency, as ovarian transplantation prevented the decline in BMD [26].
The high testosterone level apparently did not prevent bone loss in the FSHR /- mice. Ovariectomy reduced BMD and trabecular bone volume, as well as increased osteoclast surface and RANKL/OPG ratio in both $\mathrm{FSHR}^{-/}$and wildtype mice, but only osteoblast surface, mineralizing surface and bone formation rate increased in wildtype mice, indicating a higher bone turnover level [26]. The lack of osteoblastic response in $\mathrm{FSHR}^{-/-}$mice might suggest the uncoupling of bone remodelling process, although previous studies had established that FSH might not possess direct effects on osteoblasts [8]. Ovariectomy also eliminated the high circulating testosterone level in the mice [26]. Blocking the effects of testosterone using flutamide did not reduce the BMD in FSHR-/mice, but blocking the conversion of testosterone to oestrogen using letrozole, an aromatase inhibitor, did [26]. Flutamide did reduce the trabecular bone volume and increase osteoclast surface in the mice, while letrozole increased osteoclast surface and reduced osteoblast surface and bone formation rate [26]. This illustrated that oestrogen might be more important than testosterone in determining the bone health of $\mathrm{FSHR}^{-/-}$mice [26].

By using transgenic mice expressing human FSH independent of the pituitary ( $\mathrm{TgFSH})$ with or without hypogonadism, Allan et al. (2010) showed that higher FSH level was associated with higher tibial and vertebral bone volume regardless of gonadal status [27]. This observation was different from the previous study that pointed to the skeletal degenerative effects of FSH. The phenomenon might be contributed by the high testosterone and inhibin A level in FSH-high-expression mice [27]. Very high FSH also caused the formation of woven bone in marrow space and increased osteoblast surface [27]. This was not shown in TgFSH mice with moderate FSH level [27]. The results suggest that the skeletal effects of FSH, at least on bone formation, were concentration dependent. However, the osteoclast surface was similar across high FSH, moderate FSH and wildtype mice [27]. Hypogonadal TgFSH mice showed reduced $\mathrm{N}$-terminal propeptide of type I procollagen (PINP) and increased TRAP, indicative of an imbalanced bone remodelling towards bone resorption [27]. Non-hypogonadal TgFSH mice expressing high FSH also showed higher TRAP level [27]. Ovariectomy abolished the skeletal protective effects of FSH in the hypogonadal group, indicated by reduced bone volume, reduced TRAP and PINP [27]. This showed that an intact ovary was needed for the skeletal action of FSH.

Apart from genetically modified mice, supplementation of FSH on normal rodents has also been used to examine the effects the hormone on 
bone. Liu et al. (2010) supplemented $3 \mu \mathrm{g} / \mathrm{kg}$ FSH for two weeks to ovariectomized rats aged 3-4 months with periodontitis [28]. FSH increased alveolar bone loss in ovariectomized rats with periodontitis, as evidenced by increased distanced between amelocemental junction to alveolar crest, compared to untreated rats [28]. The osteoclast number at the bone crest of furcation region was increased in rats with periodontitis treated with FSH compared to untreated rats [28]. Immunohistological staining showed that the number of FSHR positive cells correlated positively with alveolar bone loss area [28]. Therefore, this study shows that high FSH aggravates bone loss in rats with pre-existing inflammatory condition.

Lukefahr et al. (2012) used 4-vinylcyclohexene diepoxide (VCD) to establish a hormonal milieu similar with premenopausal women (high FSH, normal oestrogen) in rats [29]. Distal femoral BMD was lower in VCD-treated rats starting from two months and 11 months after treatment of 160 and 80 $\mathrm{mg} / \mathrm{kg} /$ day VCD was initiated [29]. This corresponded to the changes in their hormonal milieu, whereby FSH increased consistently two months after treatment initiation in VCD-treated rats [29]. Their oestrogen level was similar with the untreated rats [29]. Correlation studies revealed a negative relationship between distal femoral BMD and FSH [29]. Therefore, this study validates that high FSH is detrimental to bone health in the presence of normal oestrogen level. However, the model used in this study might not resemble postmenopausal women entirely because the circulating inhibin A level was suppressed in VCD-treated rats but it did not happen in women undergoing menopausal transition [29].

The skeletal effects of FSH could be also illustrated by blocking its action using an antibody. Geng et al. (2013) immunized three-month-old ovariectomized rats with FSH $\beta$ antibody [30]. Three months later, they found that femoral BMD, trabecular structural indices (bone volume, thickness and number) and biomechanical indices (maximum load, stiffness, Young's modulus and stress) were significantly higher in the immunized ovariectomized rats than untreated rats [30]. Therefore, blocking the effects of FSH could partially eliminate some of the negative skeletal changes of hypogonadism in these rats.

Only one supplementation study revealed a negligible association between FSH and bone health. Ritter et al. (2008) supplemented 16-week-old male mice with 6 or $60 \mu \mathrm{g} / \mathrm{kg} /$ day FSH intermittently or 6 $\mu \mathrm{g} / \mathrm{kg} /$ day continuously via osmotic pump for one month. FSH did not alter the femoral BMD or any trabecular indices in the mice [21]. It is unclear whether the skeleton of normal male mice is less responsive of the effects of high FSH compared to female mice.

\section{Human studies}

\section{Premenopausal Women}

Many observational studies on the relationship between FSH and bone health among premenopausal women have been performed. Among 68 spontaneously menstruating women aged 45-55 years, Garton et al. (1996) showed that those with FSH level at the highest tertile (>35 IU/1) had the lowest lumbar spine and femoral BMD, lowest forearm trabecular bone density assessed by peripheral quantitative computed tomography (pQCT), and the highest serum phosphate, pyridinoline (PYD) and deoxypyridinoline (DPD) level [31]. Similarly, Cannon et al. (2010) demonstrated that FSH was the significant negative predictor of total BMD and lumbar spine BMD among 36 women aged 20-50 years with normal menstrual cycles, after adjustment for confounding factor such as oestrogenic hormones, inhibin-B, age, body anthropometry and leisure time physical activity [32]. Both studies were limited by their small sample size. Using the data from SWAN, a large multiethnicity (Caucasian, African American, Japanese, Chinese) involving 2336 women aged 42-52 years, Sowers et al. (2003) found that the relationships between FSH and femoral neck, total hip and lumbar spine BMD were negative, independent of ethnicity, physical activity and BMI of the subjects [33]. In the subsequent analysis, Sowers et al. (2003) found that a higher FSH was associated with a higher N-terminal telopeptide (NTX) level and a lower osteocalcin level. Other sex hormones were not associated with the variation in bone remodelling markers [34]. The relationship between FSH and BMD at three different phases of menses (ovulatory, anovulatory and ovulatory disturbance) was also re-examined in a subset of SWAN subjects consisting only of African American and Caucasian women $(n=643$, aged $43-53$ years). Urinary FSH was negatively and significantly associated with lumbar spine BMD at all three phases [35]. Therefore, higher FSH is associated with poorer bone health indicated by BMD and higher bone resorption indicated by bone markers, among premenopausal women as evidenced in these studies.

The association between bone health and FSH suggested by cross-sectional studies is hypothetical at best because the causal relationship cannot be assessed. Therefore, longitudinal studies were performed to validate this relationship. Among 130 non-Hispanic Caucasian women aged 31-50 years followed up for 1-9 years, Hui et al. (2002) revealed that those who lost bone faster (>1\% BMD reduction 
per year) had significant higher FSH and $\mathrm{LH}$, and lower oestradiol compared to those who lost bone slower [36]. The rate of bone loss was inversely associated with FSH level in all subjects regardless of BMD value [36]. The study was restricted by its sample size and the wide variation in follow-up period. Data from SWAN $(n=2311)$ showed that the degree of bone loss over 4 years was related with the baseline FSH level in the subjects [37]. Those with a baseline $\mathrm{FSH}<25 \mathrm{mIU} / \mathrm{ml}$ lost $0.05 \mathrm{~g} / \mathrm{cm}^{2}$ lumbar spine BMD when their follow up FSH raised to 40-70 $\mathrm{mIU} / \mathrm{ml}$. Those with a higher baseline FSH (35-45 $\mathrm{mIU} / \mathrm{ml}$ ) lost similar amount of BMD when their follow-up FSH raised to $40-50 \mathrm{mIU} / \mathrm{ml}$. The greatest lumbar spine BMD loss $\left(0.069 \mathrm{~g} / \mathrm{cm}^{2}\right)$ occurred when the follow up FSH level was $70-75 \mathrm{mIU} / \mathrm{ml}$ [37]. At 15-year follow-up, Sowers et al. (2010) divided the subjects from SWAN ( $\mathrm{n}=629$ women aged $24-44$ years at baseline) based on four FSH stages (stage $1=\mathrm{FSH}$ $<15,2=15-33,3=34-54$ and $4 \geq 54 \mathrm{mIU} / \mathrm{ml}$ ) [38]. They observed that annual spinal BMD loss was the highest for those in stage 3 and 4 . The BMD for those at stage 4 was $6.4 \%$ lower at the spine, and $5 \%$ lower at the femoral neck compared to those at stage 1. A higher BMI could attenuate the degree of bone loss [38]. The study also showed that the annual bone loss in women two years before menopause was $1.7 \%$, which indicated a significant bone loss even before oestrogen production ceased [38]. Therefore, the longitudinal studies validate that premenopausal women with higher FSH level have higher rate of bone loss.

\section{Women Across Menopausal Stages}

The relationship between FSH and bone may be dependent on menopausal status. An early study by Ebeling et al. (1996) showed that the negative relationship between FSH and femoral neck and lumbar spine BMD among 281 women aged 45-57 years diminished when menopausal status was adjusted [39]. Data from the third US National Health and Nutrition Examination Survey (3247 women aged 42-60 years) showed an inverse association between femoral BMD and FSH among perimenopausal women with high BMI and postmenopausal women with low BMI [40]. Elevated FSH level was also associated with increased risk for osteoporosis (odds ratio: 2.59 , 95\% confidence interval: $1.49-4.49$ ) after adjustment for multiple risk factors [40]. There were a number of cross-sectional studies among Asian population pertaining to this issue as well. Yasui et al. (2006) showed that spinal BMD correlated negatively with FSH and positively with oestradiol among 193 Japanese women aged 39-66 years from a university hospital [41]. Desai et al. (2007) observed that FSH was the lowest in Indian women $(n=365$, aged 20-70 years) who belonged to the highest quartiles of lumbar spine and femoral BMD [42]. Similarly, $\mathrm{Xu}$ et al. (2009) showed that FSH correlated with BMD at spine, total hip and distal forearm in 699 healthy Chinese women aged 20-82 years [43]. The prevalence of osteoporosis at $3^{\text {rd }}$ and $4^{\text {th }}$ quartile of FSH was $27.1 \pm 8.90 \%$ and $30.9 \pm 9.89 \%$ [43]. However, analysis of these three studies lacked proper adjustment for potential confounding factors. The FSH level might be a surrogate for menopausal status in these studies. $\mathrm{Wu}$ et al. (2013) estimated the BMD decrease rate among 368 healthy adult Chinese women aged 35-60 years based on the difference between measured BMD of the subjects with the reference peak BMD [44]. Lumbar spine and femoral neck BMD correlated negatively with FSH level after adjustment for age and BMI [44]. In the multivariate model including FSH, LH and oestradiol, FSH was the most important negative predictors of BMD decrease rate, explaining $18.2 \%, 33.3 \%$ and $29.9 \%$ of the variation in the rate at femoral neck, lumbar spine and ultradistal radius and ulna [44]. Therefore, it can be concluded that FSH is an important determinant of BMD in women across menopausal stages.

Cross-sectional evaluation of the association between FSH and bone remodelling markers indicated heterogenous results. Ebeling et al. (1996) noted that FSH correlated positively with bone resorption markers (urinary DPD, total PYD, NTX) and bone formation markers (alkaline phosphatase (BAP)) in pre, peri and postmenopausal Australian women [39]. Yasui et al. (2006) also showed that FSH correlated positively with intact and uncarboxylated osteocalcin in the Japanese women but they did not adjust for vitamin $\mathrm{K}$ status [41]. On the other hand, data from Rochester Epidemiology Study involving 188 Caucasian women aged 21-85 years demonstrated that FSH was not associated with any bone remodelling markers (AP, BAP, PYD, DPD) in preand postmenopausal women. C-terminal telopeptide was correlated positively with FSH in postmenopausal women before adjustment [45]. Instead, inhibin A was the best predictor for bone formation markers and oestradiol was the best predictor for bone resorption markers in these postmenopausal women [45]. Despite some inconsistencies, these studies show that high FSH is associated with increased bone remodelling characterized serum/urinary markers.

Crandall et al. (2013) followed a group of pre/perimenopausal women (aged 42-52 years) from SWAN for 10 years and examined their bone changes at before, during and after transmenopausal period [46]. During pretransmenopausal period, every doubling of FSH level was associated with a loss of 
$0.28 \%$ in the lumbar spine BMD of the subjects (vs $0.10 \%$ slower BMD loss contributed by doubling of oestrogen) [46]. In the multivariate model adjusted for oestradiol, testosterone and sex-hormone binding globulin level, only FSH was positively associated with increased lumbar spine BMD loss of $-0.32 \%$ annually [46]. During transmenopausal period, every doubling of FSH was associated with an annual $-0.33 \%$ BMD change at lumbar spine (vs - $-0.38 \%$ caused by doubling of SHBG) [46]. In the adjusted multivariate model, FSH was associated with a reduction of $0.25 \%$ BMD annually at femoral neck [46]. In late postmenopausal period, lumbar spine BMD loss was associated with oestrogen and SHBG level but not with FSH. No hormone was predictive of femoral neck BMD loss in this period [46]. This highlighted the significant role of FSH in bone loss during pre/perimenopausal period, but not postmenopausal when the effects of oestrogen deficiency are prominent.

\section{Postmenopausal women}

Several studies scrutinized the skeletal effects of FSH in the postmenopausal population to validate the speculation aforementioned. In 111 communitydwelling multi-ethnic postmenopausal women aged 50-64 years, Gourlay et al. (2011) indicated that both FSH and oestradiol were not significantly associated with BMD at lumbar spine, femoral neck, total hip and distal radius in adjusted multivariate models [47]. However, it was a significant negative predictor for trabecular volumetric BMD assessed by pQCT in these women [47]. In the subsequent analysis (94 postmenopausal women aged 50-64 years) considering body composition, FSH was significantly and negatively associated with lean mass and bone mass but not BMD [48]. Since Bonferroni adjustment, a very conservative approach, was performed in both studies, type II error (false negative) might be inflated. Wang et al. (2015) found a negative correlation between forearm BMD and FSH level in 248 Chinese women aged $>50$ years (128 were osteoporotic and 120 had normal bone health) but the analysis was not adjusted for confounding factors [20]. The osteoporotic subjects were shown to have a higher FSH and lower oestradiol level in each age group [20]. From these studies, it is observed that the relationship between FSH and bone health is between negative to negligible in postmenopausal women. However, causality cannot be inferred because no longitudinal studies on the association between FSH and bone in postmenopausal women have been published.

A gene polymorphism study among 289 postmenopausal women aged 50-75 years showed that BAP and CTX-1 levels were higher, and femoral neck and total body BMD were lower in postmenopausal women with AA (Asn680/Asn680) rs6166 compared with those with GG (Ser680/Ser680) rs6166 FSHR genotype [49]. Women with AG (Ser680/Asn680) genotype also showed significantly lower femoral neck and total body BMD and quantitative ultrasound stiffness index compared to those with GG genotype [49]. Multiple regression analysis confirmed that women with AA genotype had increased risk for osteoporosis (odds ratio: 1.87, 95\% CI: 1.18-2.70) and osteopenia (odds ratio: 1.75, 95\% CI: 1.25-2.26) compared to GG genotype after adjustment for various confounding factors. Besides, more subjects with the AA genotype experienced at least one clinical fracture compared to GG genotype [49]. This showed that polymorphism of the FSH gene could influence the bone health of women beyond menopausal age.

\section{Men}

Osteoporosis is traditionally linked to the gradual decline of testosterone due to age [50,51]. Two independent studies have examined the relationship between FSH and bone in men. In a case control study by Karim et al. (2008) involving 63 community-dwelling osteoporotic and 93 normal men in UK (aged 57.7 \pm 13.7 years), FSH was a significant negative predictor of BMD at lumbar spine, femoral neck and hip in an adjusted multivariate model [52]. The relationship persisted when case and control were analysed separately [52]. Hsu et al. (2015) analysed the data from the Concord Health and Ageing in Men Project, which followed 1705 men aged $>70$ years for 5 years [53]. The baseline FSH level was negatively associated with BMD change in univariate and multivariate analysis adjusted for age, BMI, smoking status, physical activity and number of comorbidities [53]. High FSH was also associated with a higher risk for all types of fracture and hip fracture in univariate model but after adjustment in multivariate model, the association was rendered not significant [53]. The authors suggested that since testosterone was not associated with BMD of the subjects, the relationship between bone and FSH could be independent of the androgenic status in these men [53]. Despite the limited number of studies compared to women, the current evidence suggests a negative association between bone health and FSH level in men.

\section{Experiment by nature or human}

Hyper- and hypogonadotropic conditions induced by diseases and drugs provide an opportunity to study the relationship between FSH and bone in humans. Devleta et al. (2004) studied the 
spinal and femoral BMD of hypergonadotropic (FSH $>40 \quad \mathrm{IU} / \mathrm{l} ; \mathrm{n}=7$; aged $37.43 \pm 3.10$ years) and hypogonadotropic (FSH $<40$ IU $/ 1 ; n=15 ;$ aged $29.8 \pm 5.71$ years) amenorrhoeic and eumenorrheic women ( $\mathrm{n}=12$; aged $33.81 \pm 5.89$ years $)$ [54]. As expected, the amenorrhoeic women had lower lumbar spine T-score compared to eumenorrheic women [54]. Despite the difference in oestradiol level was not statistically significant, hypergonadotropic women were found to have a significant lower lumbar spine BMD than hypogonadotropic women [54]. In a group of women aged $45.9 \pm 5.5$ years diagnosed with breast cancer and receiving cancer chemotherapy for at least one year, FSH was associated with the degree of BMD loss at lumbar spine and femoral neck since treatment initiation [55]. The rate of bone loss at lumbar spine was the highest in the highest tertile of FSH [55]. In addition, BMD at femoral neck and hip, CTX, PINP and osteocalcin were the lowest in the highest tertile of FSH [55]. However, the use of tamoxifen, a known agent that increases BMD, was not adjusted in this study [55]. These studies show that alteration of FSH level due to diseases or drugs could also influence bone health in humans.

The bone remodelling markers and BMD of adolescent women with Kallman syndrome (hypogonadotropic; $n=8$ ), Turner syndrome (hypergonadotropic; $n=11$ ) and pure gonadal dygenesia (hypergonadotropic; $n=11$ ) were compared [56]. Women with Kallman syndrome had the lowest lumbar spine and hip BMD compared to women with the other two conditions, although the NTX was not significantly different among them [56]. There was a significant negative relationship between FSH and spinal BMD in unadjusted correlation test [56]. After adjustment for growth hormone therapy, the association was lost [56]. In another study, no correlation was found between FSH and total or lumbar spine BMD among 76 long-term survivors treated for paediatric cancer (43 men and 33 women, aged $24.1 \pm 3.5$ years) [57]. Due to the small sample size and heterogeneity of the conditions and treatments in both studies, it is difficult to interpret the relationship between FSH level and bone health in the subjects.

In a clinical trial, post-menopausal women were randomized into leuprolide $(7.5 \mathrm{mg}$ i.m. every 28 days; $n=21$ aged $67.4 \pm 1.2$ years) and placebo group $(n=20$ aged $66.1 \pm 1.3$ years) [58]. Both group received letrozole, an aromatase inhibitor to prevent exogenous synthesis of oestradiol [58]. At the end of the experiment, both group experienced a significant increase in CTX and TRAP5b level [58]. Only the leuprolide group showed increased PINP level [58]. Therefore, the inhibition of FSH through leuprolide did not prevent high bone remodelling, but rather enhanced it. Since these women were menopausal, the effects of FSH might be different from women in other stages of life.

The epidemiological studies regarding the relationship between FSH and bone health in humans are summarized in Table 1.

Table 1. The relationship between FSH and bone health in humans.

\begin{tabular}{|c|c|c|c|c|c|}
\hline \multirow[t]{2}{*}{ Authors } & \multirow[t]{2}{*}{ Study design } & \multicolumn{4}{|c|}{ Relationship with variables } \\
\hline & & BMD & $\begin{array}{l}\text { Bone remodelling } \\
\text { markers }\end{array}$ & pQCT & Fracture \\
\hline \multicolumn{6}{|l|}{ Premenopausal Women } \\
\hline Garton et al. 1996 [31] & $\begin{array}{l}68 \text { spontaneously menstruating women aged } 45-55 \text { years. The subjects } \\
\text { were divided based on tertiles of FSH level }(<10 \mathrm{U} / 1 ; 10-35 \mathrm{U} / \mathrm{l} ;>35 \mathrm{U} / \mathrm{l}) \text {. }\end{array}$ & Negative & $\begin{array}{l}\text { Serum phosphate, PYD, } \\
\text { DYD: positive }\end{array}$ & & \\
\hline Sowers et al. 2003 [33] & $\begin{array}{l}2336 \text { women aged } 42-52 \text { years (pre and peri menopause) from the Study of } \\
\text { Women's Health Across the Nation (SWAN). Composition of the subjects } \\
\text { were } 28.2 \% \text { African-American, } 49.9 \% \text { Caucasian, } 10.5 \% \text { Japanese or } 11.4 \% \\
\text { Chinese. }\end{array}$ & Negative & & & \\
\hline Sowers et al. 2003 [34] & $\begin{array}{l}\text { 2,375 pre- and early perimenopausal women from SWAN, aged } 42-52 \\
\text { years. Multiethnicities. }\end{array}$ & & $\begin{array}{l}\text { NTX: positive } \\
\text { Osteocalcin: negative }\end{array}$ & & \\
\hline Grewal et al. 2006 [35] & $\begin{array}{l}643 \text { pre- and perimenopausal women, aged } 43-53 \text { years from SWAN. BMD } \\
\text { at lumbar spine and femoral hip was measured. }\end{array}$ & Negative & & & \\
\hline Cannon et al. 2010 [32] & 36 women aged 20-50 years with normal natural menstrual cycles. & Negative & & & \\
\hline Vural et al. 2005 [59] & 87 healthy volunteers from the community aged $35-50$ years. & Not significant & $\begin{array}{l}\text { NTX: positive } \\
\text { Osteocalcin: not } \\
\text { significant }\end{array}$ & & \\
\hline Hui et al. 2002 [36] & $\begin{array}{l}130 \text { non-Hispanic white women aged } 31-50 \text { years. Followed up at least } 3 \\
\text { times for } 1-9 \text { years. }\end{array}$ & Negative & & Negative & \\
\hline Sowers et al. 2006 [37] & $\begin{array}{l}\text { 4-year longitudinal study of the SWAN cohort. } 2311 \text { premenopausal or } \\
\text { early perimenopausal African-American, Caucasian, Chinese, and } \\
\text { Japanese women. }\end{array}$ & Negative & & & \\
\hline Sowers et al. 2010 [38] & $\begin{array}{l}629 \text { women aged } 24-44 \text { years at baseline were followed up for } 15 \text { years. } \\
\text { Subjects were divided into FSH stages } 1-4: 1=<15,2=15-33,3=34-54,4=>54 \\
\mathrm{mlU} / \mathrm{ml} \text {. }\end{array}$ & Negative & & & \\
\hline Crandall et al. 2013 [46] & $\begin{array}{l}\text { A } 10 \text {-year follow up of } 720 \text { women in SWAN cohort. Subjects aged } 42-52 \\
\text { (mean 46.2) years at baseline. }\end{array}$ & Negative & & & \\
\hline \multicolumn{6}{|c|}{ Women across menopausal stages } \\
\hline Ebeling et al. 1996 [39] & $\begin{array}{l}281 \text { women aged } 45-57 \text { years (pre, peri and postmenopausal groups) } \\
\text { selected from a larger randomized urban population cohort (Melbourne }\end{array}$ & $\begin{array}{l}\text { Not significant } \\
\text { after }\end{array}$ & $\begin{array}{l}\text { uDPD, total PYD, NTX, } \\
\text { BAP: positive }\end{array}$ & & \\
\hline
\end{tabular}




\begin{tabular}{|c|c|c|c|c|c|}
\hline \multirow[t]{2}{*}{ Authors } & \multirow[t]{2}{*}{ Study design } & \multicolumn{4}{|c|}{ Relationship with variables } \\
\hline & & BMD & $\begin{array}{l}\text { Bone remodelling } \\
\text { markers }\end{array}$ & pQCT & Fracture \\
\hline & Women's Midlife Health Project). & adjustment & & & \\
\hline Perrien et al. 2006 [45] & $\begin{array}{l}188 \text { pre- and postmenopausal women not using oral contraceptives or } \\
\text { hormone replacement therapy (age, 21-85 yr) from Rochester } \\
\text { Epidemiology Project. Only } 2 \text { subjects were non-Caucasians. }\end{array}$ & & $\begin{array}{l}\text { CTX: positive } \\
\text { AP, BAP, PYD, DPD: Not } \\
\text { significant }\end{array}$ & & \\
\hline Yasui et al. 2006 [41] & $\begin{array}{l}\text { Cross-sectional study. } 193 \text { female outpatients of a Japanese university } \\
\text { hospital aged } 39-66 \text { years. } 40 \text { were premenopause, } 47 \text { were perimenopause, } \\
106 \text { were postmenopause stage. Serum biochemical markers measured } \\
\text { included uncarboxylated osteocalcin, intact osteocalcin, bone alkaline } \\
\text { phosphatase, urinary N-telopeptide, LH, FSH, oestradiol, estrone. }\end{array}$ & Negative & $\begin{array}{l}\text { Osteocalcin (intact and } \\
\text { uncarboxylated): Positive }\end{array}$ & & \\
\hline Desai et al. 2007 [42] & 365 Indian women aged 20-70 years from a community-based clinic. & Negative & & & \\
\hline Xu et al. 2009 [43] & $\begin{array}{l}\text { Cross-sectional study. } 699 \text { healthy Chinese women aged } 20-82 \text { years. } \\
\text { Serum LH, FSH measured. BMD measured at posteroanterior spine, lateral } \\
\text { spine, TH and distal forearm. }\end{array}$ & Negative & & & \\
\hline $\begin{array}{l}\text { Gallagher et al. } 2010 \\
\text { [40] }\end{array}$ & $\begin{array}{l}3247 \text { peri- and postmenopausal women aged } 42-60 \text { years from US National } \\
\text { Health and Nutrition Examination Survey (NHANESIII). }\end{array}$ & Negative & & & \\
\hline Wu et al. 2013 [44] & $\begin{array}{l}\text { Cross-sectional study. } 368 \text { healthy adult Chinese women ( } 155 \\
\text { premenopausal women, } 63 \text { perimenopausal, } 150 \text { postmenopausal women), } \\
\text { aged } 35-60 \text { years. }\end{array}$ & Negative & & & \\
\hline \multicolumn{6}{|l|}{ Post-menopausal Women } \\
\hline Gourlay et al. 2011 [47] & $\begin{array}{l}111 \text { community-dwelling postmenopausal women aged } 50-64 \text { years (mean } \\
57.5 \pm 3.7 \text { ) from various ethnicities. }\end{array}$ & $\begin{array}{l}\text { Negative but } \\
\text { lost after } \\
\text { adjustment }\end{array}$ & & & \\
\hline Gourlay et al. 2012 [48] & $\begin{array}{l}94 \text { younger (aged } 50 \text { to } 64 \text { years, mean } 57.5 \text { years) community dwelling } \\
\text { postmenopausal women not using HRT. }\end{array}$ & & & Negative & \\
\hline Wang et al. 2015 [20] & $\begin{array}{l}248 \text { postmenopausal Chinese women aged } 50 \text { years or above ( } 128 \\
\text { osteoporotic and } 120 \text { normal bone health) }\end{array}$ & Negative & & & \\
\hline \multicolumn{6}{|c|}{ 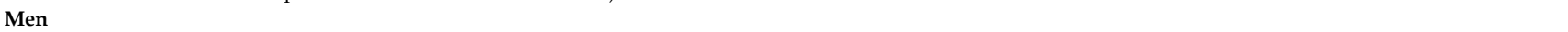 } \\
\hline Karim et al. 2008 [52] & $\begin{array}{l}\text { Case-control study. } 156 \text { community-dwelling men in London UK aged } 57.7 \\
\pm 13.7 \text { years. } 63 \text { osteoporotic men, } 93 \text { normal control. }\end{array}$ & Negative & & & Not significant \\
\hline Hsu et al. 2015 [53] & $\begin{array}{l}1705 \text { men aged } 70 \text { years and older from the Concord Health and Ageing in } \\
\text { Men Project were followed up for } 5 \text { years. }\end{array}$ & Negative & & & \\
\hline \multicolumn{6}{|c|}{ Experimental by nature or human } \\
\hline Kawai et al. 2004 [60] & $\begin{array}{l}\text { A retrospective study on } 125 \text { women undergoing hormone replacement } \\
\text { therapy. Sequential measurement of hormone was performed before, at } 12 \\
\text { and } 24 \text { months after starting hormone replacement therapy. }\end{array}$ & Negative & & & \\
\hline Devleta et al. 2004 [54] & $\begin{array}{l}7 \text { hypergonadotropic }(\mathrm{FSH}>40 \mathrm{IU} / \mathrm{l} \text {; aged } 37.43 \pm 3.10), 15 \\
\text { hypogonadotropic (FSH }<40 \mathrm{IU} / 1 \text {; aged } 29.8 \pm 5.71) \text { amenorrhoeic and } 12 \\
\text { eumenorrheic women (aged } 33.81 \pm 5.89 \text { ) were recruited. }\end{array}$ & Negative & & & \\
\hline $\begin{array}{l}\text { Castelo-Branco et al. } \\
2008 \text { [56] }\end{array}$ & $\begin{array}{l}8 \text { adolescent women with Kallman syndrome (hypogonadotropic); } 11 \text { with } \\
\text { Turner syndrome (hypergonadotropic); } 11 \text { with pure gonadal dysgenesia } \\
\text { (hypergonadotropic). }\end{array}$ & $\begin{array}{l}\text { Not significant } \\
\text { after } \\
\text { adjustment }\end{array}$ & & & \\
\hline Drake et al. 2010 [58] & $\begin{array}{l}\text { Post-menopausal women were randomized into two groups. One group } \\
(\mathrm{n}=21 \text {, aged } 67.4 \pm 1.2) \text { received leuprolide }(7.5 \mathrm{mg} \text { i.m. every } 28 \mathrm{~d}) \text { and the } \\
\text { other group }(\mathrm{n}=20 \text {, aged } 66.1 \pm 1.3 \text { years) received placebo. Both groups } \\
\text { received aromatase inhibitor (letrozole, } 2.5 \mathrm{mg} / \mathrm{d}) \text { to prevent exogenous } \\
\text { synthesis of oestradiol. }\end{array}$ & & $\begin{array}{l}\text { High bone turnover not } \\
\text { inhibited. }\end{array}$ & & \\
\hline Latoch et al. 2015 [57] & $\begin{array}{l}76 \text { long-term survivors ( } 43 \text { men and } 33 \text { women) treated for paediatric } \\
\text { cancer. } 38 \% \text { leukaemia, } 36 \% \text { lymphoma, } 26 \% \text { solid tumours. Age at the } \\
\text { study was } 24.1 \pm 3.5 \text { years }\end{array}$ & Not significant & & & \\
\hline $\begin{array}{l}\text { Tabatabai et al. } 2016 \\
\text { [55] }\end{array}$ & $\begin{array}{l}206 \text { women }(64 \% \text { white) age } \leq 55 \text { (mean } 45.9 \pm 5.5 \text { ) years at breast cancer } \\
\text { diagnosis receiving adjuvant cancer chemotherapy and at least } 1 \text { year after } \\
\text { diagnosis. }\end{array}$ & Negative & $\begin{array}{l}\text { CTX, PINP, osteocalcin: } \\
\text { positive } \\
\text { AP, NTX: Not significant }\end{array}$ & & \\
\hline
\end{tabular}

Abbreviation:

$\mathrm{AP}=$ alkaline phosphatase; $\mathrm{BAP}=$ bone-specific alkaline phosphatase; $\mathrm{BMD}=$ bone mineral density; $\mathrm{DPD}=$ deoxypyridinoline; $\mathrm{CTX}=\mathrm{C}$-terminal telopeptide of type $\mathrm{I}$ collagen; $\mathrm{FSH}=$ follicle-stimulating hormone; NTX=N-terminal telopeptide of type I collagen; $\mathrm{PINP}=\mathrm{N}$-terminal propeptide of type I procollagen; $\mathrm{pQCT}=$ peripheral quantitative computed tomography; PYD=pyridinoline

\section{Conclusion}

FSH has a direct effect on bone resorption mediated by FSHR receptors found on osteoclasts and their precursors. The effects of FSH on osteoblasts could be negligible since they do not express FSHR. Transgenic rodent model showed heterogenous results on the skeletal effects of FSH, which seem to be dependent on the ovarian production of testosterone in rodents lacking FSH and FSHR. Supplementing FSH in rats has been shown to be detrimental to the bone, while blocking its activity seems to be beneficial to the skeleton. The human studies generally reveal a significant and negative relationship between FSH level and bone health but the relationship diminishes after menopause, when the effects of oestrogen deficiency are dominant. Thus, FSH may partially explain bone loss during perimenopausal period. Skeletal deterioration in hypogonadotropic hypogonadism may occur because the influence of sex hormone deficiency is greater than FSH deficiency. Similar negative relationship between FSH and bone health is observed in men.

Several research gaps need to be bridged to validate the relationship between FSH and bone health. The current evidence is predominantly from 
cross-sectional studies which prevents the interpretation of causality. More longitudinal investigations on the effects of FSH on bone health, especially fracture risk in women, should be made. More studies on men should also be performed because their FSH level and fracture risk also increase gradually with age. In addition to that, post-fracture mortality rate of men is higher than women, which necessitates a better understanding of male osteoporosis and its predictors like FSH. Since the hormonal changes across life stages is complex, there is a need to understand the influence of not just FSH alone, but also other related hormone factors, or the whole hormonal milieu alternation on bone health. While the use of anti-FSH antibody to stop bone loss is tempting, there is insufficient evidence currently, to support that blocking the effects of FSH during perimenopause period exerts skeletal beneficial in humans. We hope that more enlightening discoveries in the future will lead to a better understanding of the involvement of $\mathrm{FSH}$ in the pathogenesis of osteoporosis in aging women and men. Hopefully, this will spark more innovative and safer interventions to halt bone loss by manipulating the hormonal milieu.

\section{Acknowledgements}

The author wishes to acknowledge Universiti Kebangsaan Malaysia for funding his studies via grants GUP-2017-060 and AP-2017-009/1. He also thanks Miss Shu Shen Tay for proofreading the manuscript.

\section{Competing Interests}

The authors have declared that no competing interest exists.

\section{References}

1. Finkelstein JS, Brockwell SE, Mehta V, Greendale GA, Sowers MR, Ettinger B, et al. Bone mineral density changes during the menopause transition in a multiethnic cohort of women. J Clin Endocrinol Metab. 2008; 93: 861-8.

2. Rannevik G, Jeppsson S, Johnell O, Bjerre B, Laurell-Borulf Y, Svanberg L. A longitudinal study of the perimenopausal transition: altered profiles of steroid and pituitary hormones, SHBG and bone mineral density. Maturitas. 1995; 21: 103-13.

3. Randolph JF, Jr., Zheng H, Sowers MR, Crandall C, Crawford S, Gold EB, et al. Change in follicle-stimulating hormone and estradiol across the menopausal transition: effect of age at the final menstrual period. J Clin Endocrinol Metab. 2011; 96: 746-54.

4. Ogawa S, Fujita M, Ishii Y, Tsurukami H, Hirabayashi M, Ikeda K, et al. Impaired Estrogen Sensitivity in Bone by Inhibiting Both Estrogen Receptor a and $\beta$ Pathways. J Biol Chem. 2000; 275: 21372-9.

5. Windahl SH, Hollberg K, Vidal O, Gustafsson JA, Ohlsson C, Andersson G. Female estrogen receptor beta-/- mice are partially protected against age-related trabecular bone loss. J Bone Miner Res. 2001; 16: 1388-98.

6. Windahl SH, Vidal O, Andersson G, Gustafsson JA, Ohlsson C. Increased cortical bone mineral content but unchanged trabecular bone mineral density in female ERbeta(-/-) mice. J Clin Invest. 1999; 104: 895-901.

7. Yeh JK, Chen MM, Aloia JF. Ovariectomy-induced high turnover in cortical bone is dependent on pituitary hormone in rats. Bone. 1996; 18: 443-50.

8. Sun L, Peng Y, Sharrow AC, Iqbal J, Zhang Z, Papachristou DJ, et al. FSH directly regulates bone mass. Cell. 2006; 125: 247-60.
9. Mohamad NV, Soelaiman IN, Chin KY. Effect of Androgen Deprivation Therapy (ADT) on Bone Health Status in Men with Prostate Cancer. Endocr Metab Immune Disord Drug Targets. 2017; 17: 276 - 84.

10. Mohamad N-V, Zulkepli MAAC, Theseira KM, Zulkifli N, Shahrom NQNAMR, Jamil NA, et al. Establishing an Animal Model of Secondary Osteoporosis by Using a Gonadotropin-releasing Hormone Agonist. Int J Med Sci. 2018; 15: 300-8

11. Mohamad NV, Ima-Nirwana S, Chin KY. The effects of gonadotropin-releasing hormone agonist (buserelin) and orchidectomy on bone turnover markers and histomorphometry in rats. Aging Male. 2018: in press.

12. Levin VA, Jiang X, Kagan R. Estrogen therapy for osteoporosis in the modern era. Osteoporos Int. 2018: in press.

13. Peng L, Luo Q, Lu H. Efficacy and safety of bazedoxifene in postmenopausal women with osteoporosis: A systematic review and meta-analysis. Medicine (Baltimore). 2017; 96: e8659.

14. Gambacciani M, Levancini M. Management of postmenopausal osteoporosis and the prevention of fractures. Panminerva Med. 2014; 56: 115-31.

15. Robinson LJ, Tourkova I, Wang Y, Sharrow AC, Landau MS, Yaroslavskiy BB, et al. FSH-Receptor Isoforms and FSH-dependent Gene Transcription in Human Monocytes and Osteoclasts. Biochemical and biophysical research communications. 2010; 394: 12-7.

16. Zhu L-L, Tourkova I, Yuen T, Robinson LJ, Bian Z, Zaidi M, et al. Blocking FSH action attenuates osteoclastogenesis. Biochemical and Biophysical Research Communications. 2012; 422: 54-8.

17. Iqbal J, Sun L, Kumar TR, Blair HC, Zaidi M. Follicle-stimulating hormone stimulates TNF production from immune cells to enhance osteoblast and osteoclast formation. Proc Natl Acad Sci U S A. 2006; 103: 14925-30.

18. Sun L, Zhang Z, Zhu L-L, Peng Y, Liu X, Li J, et al. Further evidence for direct pro-resorptive actions of FSH. Biochemical and Biophysical Research Communications. 2010; 394: 6-11.

19. Cannon JG, Kraj B, Sloan G. Follicle-stimulating hormone promotes RANK expression on human monocytes. Cytokine. 2011; 53: 141-4.

20. Wang J, Zhang W, Yu C, Zhang X, Zhang H, Guan O, et al. Follicle-Stimulating Hormone Increases the Risk of Postmenopausal Osteoporosis by Stimulating Osteoclast Differentiation. PLoS One. 2015; 10: e0134986.

21. Ritter V, Thuering B, Saint Mezard P, Luong-Nguyen NH, Seltenmeyer Y, Junker U, et al. Follicle-stimulating hormone does not impact male bone mass in vivo or human male osteoclasts in vitro. Calcif Tissue Int. 2008; 82: 383-91.

22. Su XY, Zou X, Chen QZ, Zeng YH, Shao Y, He BC, et al. Follicle-Stimulating Hormone beta-Subunit Potentiates Bone Morphogenetic Protein 9-Induced Osteogenic Differentiation in Mouse Embryonic Fibroblasts. J Cell Biochem. 2017; 118: 1792-802.

23. Seibel MJ, Dunstan CR, Zhou H, Allan CM, Handelsman DJ. Sex steroids, not FSH, influence bone mass. Cell. 2006; 127: 1079

24. Abel MH, Huhtaniemi I, Pakarinen P, Kumar TR, Charlton HM. Age-related uterine and ovarian hypertrophy in FSH receptor knockout and FSHbeta subunit knockout mice. Reproduction. 2003; 125: 165-73.

25. Balla A, Danilovich N, Yang Y, Sairam MR. Dynamics of ovarian development in the FORKO immature mouse: structural and functional implications for ovarian reserve. Biol Reprod. 2003; 69: 1281-93.

26. Gao J, Tiwari-Pandey R, Samadfam R, Yang Y, Miao D, Karaplis AC, et al. Altered ovarian function affects skeletal homeostasis independent of the action of follicle-stimulating hormone. Endocrinology. 2007; 148: 2613-21.

27. Allan CM, Kalak R, Dunstan CR, McTavish KJ, Zhou H, Handelsman DJ, et al. Follicle-stimulating hormone increases bone mass in female mice. Proc Natl Acad Sci U S A. 2010; 107: 22629-34.

28. Liu S, Cheng Y, Fan M, Chen D, Bian Z. FSH aggravates periodontitis-related bone loss in ovariectomized rats. J Dent Res. 2010: 89: 366-71.

29. Lukefahr AL, Frye JB, Wright LE, Marion SL, Hoyer PB, Funk JL. Decreased bone mineral density in rats rendered follicle-deplete by an ovotoxic chemical correlates with changes in follicle-stimulating hormone and inhibin A. Calcif Tissue Int. 2012; 90: 239-49.

30. Geng W, Yan X, Du H, Cui J, Li L, Chen F. Immunization with FSHbeta fusion protein antigen prevents bone loss in a rat ovariectomy-induced osteoporosis model. Biochem Biophys Res Commun. 2013; 434: 280-6.

31. Garton M, Martin J, New S, Lee S, Loveridge N, Milne J, et al. Bone mass and metabolism in women aged 45-55. Clin Endocrinol (Oxf). 1996; 44: 563-70.

32. Cannon JG, Cortez-Cooper M, Meaders E, Stallings J, Haddow S, Kraj B, et al. Follicle-stimulating hormone, interleukin-1, and bone density in adult women. Am J Physiol Regul Integr Comp Physiol. 2010; 298: R790-8.

33. Sowers MR, Finkelstein JS, Ettinger B, Bondarenko I, Neer RM, Cauley JA, et al. The association of endogenous hormone concentrations and bone mineral density measures in pre- and perimenopausal women of four ethnic groups: SWAN. Osteoporos Int. 2003; 14: 44-52.

34. Sowers MR, Greendale GA, Bondarenko I, Finkelstein JS, Cauley JA, Neer RM, et al. Endogenous hormones and bone turnover markers in pre- and perimenopausal women: SWAN. Osteoporos Int. 2003; 14: 191-7.

35. Grewal J, Sowers MR, Randolph JF, Jr., Harlow SD, Lin X. Low bone mineral density in the early menopausal transition: role for ovulatory function. J Clin Endocrinol Metab. 2006; 91: 3780-5.

36. Hui SL, Perkins AJ, Zhou L, Longcope C, Econs MJ, Peacock M, et al. Bone loss at the femoral neck in premenopausal white women: effects of weight change and sex-hormone levels. J Clin Endocrinol Metab. 2002; 87: 1539-43. 
37. Sowers MR, Jannausch M, McConnell D, Little R, Greendale GA, Finkelstein JS, et al. Hormone predictors of bone mineral density changes during the menopausal transition. J Clin Endocrinol Metab. 2006; 91: 1261-7.

38. Sowers MR, Zheng H, Jannausch ML, McConnell D, Nan B, Harlow S, et al. Amount of bone loss in relation to time around the final menstrual period and follicle-stimulating hormone staging of the transmenopause. J Clin Endocrinol Metab. 2010; 95: 2155-62.

39. Ebeling PR, Atley LM, Guthrie JR, Burger HG, Dennerstein L, Hopper JL, et al. Bone turnover markers and bone density across the menopausal transition. J Clin Endocrinol Metab. 1996; 81: 3366-71.

40. Gallagher CM, Moonga BS, Kovach JS. Cadmium, follicle-stimulating hormone, and effects on bone in women age 42-60 years, NHANES III. Environ Res. 2010; 110: 105-11.

41. Yasui T, Uemura $\mathrm{H}$, Tomita J, Miyatani $\mathrm{Y}$, Yamada M, Miura M, et al. Association of serum undercarboxylated osteocalcin with serum estradiol in pre-, peri- and early post-menopausal women. J Endocrinol Invest. 2006; 29: 913-8.

42. Desai Meena P, Khatkhatay MI, Bhanu Prakash KV, Savardekar LS, Shah RS, Ansari Z. Hormonal profiles and biochemical indices of bone turnover in Indian women. Osteoporos Int. 2007; 18: 923-9.

43. Xu ZR, Wang AH, Wu XP, Zhang H, Sheng ZF, Wu XY, et al. Relationship of age-related concentrations of serum FSH and LH with bone mineral density, prevalence of osteoporosis in native Chinese women. Clin Chim Acta. 2009; 400: 8-13.

44. Wu XY, Yu SJ, Zhang H, Xie H, Luo XH, Peng YQ, et al. Early bone mineral density decrease is associated with FSH and LH, not estrogen. Clin Chim Acta. 2013; 415: 69-73.

45. Perrien DS, Achenbach SJ, Bledsoe SE, Walser B, Suva LJ, Khosla S, et al. Bone turnover across the menopause transition: correlations with inhibins and follicle-stimulating hormone. J Clin Endocrinol Metab. 2006; 91: 1848-54.

46. Crandall CJ, Tseng $\mathrm{CH}$, Karlamangla AS, Finkelstein JS, Randolph JF, Jr., Thurston RC, et al. Serum sex steroid levels and longitudinal changes in bone density in relation to the final menstrual period. J Clin Endocrinol Metab. 2013; 98: E654-63.

47. Gourlay ML, Preisser JS, Hammett-Stabler CA, Renner JB, Rubin J. Follicle-stimulating hormone and bioavailable estradiol are less important than weight and race in determining bone density in younger postmenopausal women. Osteoporos Int. 2011; 22: 2699-708.

48. Gourlay ML, Specker BL, Li C, Hammett-Stabler CA, Renner JB, Rubin JE. Follicle-stimulating hormone is independently associated with lean mass but not BMD in younger postmenopausal women. Bone. 2012; 50: 311-6.

49. Rendina D, Gianfrancesco F, De Filippo G, Merlotti D, Esposito T, Mingione A, et al. FSHR gene polymorphisms influence bone mineral density and bone turnover in postmenopausal women. Eur J Endocrinol. 2010; 163: 165-72.

50. Chin KY, Ima-Nirwana S. Sex steroids and bone health status in men. Int J Endocrinol. 2012; 2012: 208719.

51. Mohamad NV, Soelaiman IN, Chin KY. A concise review of testosterone and bone health. Clin Interv Aging. 2016; 11: 1317-24

52. Karim N, MacDonald D, Dolan AL, Fogelman I, Wierzbicki AS, Hampson G. The relationship between gonadotrophins, gonadal hormones and bone mass in men. Clin Endocrinol (Oxf). 2008; 68: 94-101.

53. Hsu B, Cumming RG, Seibel MJ, Naganathan V, Blyth FM, Bleicher K, et al. Reproductive Hormones and Longitudinal Change in Bone Mineral Density and Incident Fracture Risk in Older Men: The Concord Health and Aging in Men Project. J Bone Miner Res. 2015; 30: 1701-8.

54. Devleta B, Adem B, Senada S. Hypergonadotropic amenorrhea and bone density: new approach to an old problem. J Bone Miner Metab. 2004; 22: 360-4.

55. Tabatabai LS, Bloom J, Stewart S, Sellmeyer DE. FSH Levels Predict Bone Loss in Premenopausal Women Treated for Breast Cancer More Than One Year After Treatment. J Clin Endocrinol Metab. 2016; 101: 1257-62.

56. Castelo-Branco C, Leon M, Duran M, Balasch J. Follicle-stimulating hormone does not directly regulate bone mass in human beings: evidence from nature. Fertil Steril. 2008; 90: 2211-6.

57. Latoch E, Muszynska-Roslan K, Panas A, Panasiuk A, Rutkowska-Zelazowska B, Konstantynowicz J, et al. Bone mineral density, thyroid function, and gonadal status in young adult survivors of childhood cancer. Contemp Oncol (Pozn). 2015; 19: 142-7.

58. Drake MT, McCready LK, Hoey KA, Atkinson EJ, Khosla S. Effects of suppression of follicle-stimulating hormone secretion on bone resorption markers in postmenopausal women. J Clin Endocrinol Metab. 2010; 95: 5063-8.

59. Vural F, Vural B, Yucesoy I, Badur S. Ovarian aging and bone metabolism in menstruating women aged 35-50 years. Maturitas. 2005; 52: 147-53.

60. Kawai H, Furuhashi M, Suganuma N. Serum follicle-stimulating hormone level is a predictor of bone mineral density in patients with hormone replacement therapy. Arch Gynecol Obstet. 2004; 269: 192-5. 